\title{
PENGARUH REBUSAN DAUN SALAM TERHADAP PENURUNAN KADAR ASAM URAT PADA LANSIA
}

\author{
Widiyono $^{1}$, Atik Aryani ${ }^{1}$, Rara Ayu Sartagus ${ }^{2}$ \\ ${ }^{1}$ Universitas Sahid Surakarta \\ ${ }^{2}$ Klinik dr. Widodo, Gemolong \\ Email:widiyono2727@gmail.com
}

\begin{abstract}
Abstrak
Daun salam (Eugenia polyantha Wight) yang biasa dimanfaatkan oleh masyarakat Indonesia sebagai pelengkap bumbu dapur juga mempunyai khasiat sebagai obat. Dalam pengobatan, daun salam digunakan untuk pengobatan kolesterol tinggi, kencing manis (diabetes mellitus), tekanan darah tinggi (hipertensi), sakit maag (gastritis), diare dan kandungan kimianya mempunyai aktivitas sebagai obat asam urat. Tujuan dari penelitian ini adalah untuk mengetahui pengaruh rebusan daun salam terhadap penurunan kadar asam urat. Desain penelitian yang digunakan adalah quasi experimental design, serta rancangan penelitian yang akan digunakan penulis adalah one group pre test-post test design. Sampel penelitian adalah lansia di Posyandu Ngembat Padas Sragen yaitu sebanyak 36 orang lansia. Teknik pengambilan sampel dilakukan secara purposive sampling. Analisis data dilakukan dengan uji normalitas data menggunakan Shapiro-Wilk yang dilanjutkan analisis dengan menggunakan uji statistik parametric dengan paired sample $t$-test. Berdasarkan hasil analisis menggunakan uji statistik parametric dengan paired samplet-test dengan paired test menunjukan $p$-value $=0,001<\alpha(0,05)$. dengan hasil uji $t$-test dengan selisih -2,51 (IK95\%-3,03 sampai -1,99) yang berarti H0 ditolak berarti menunjukan adanya perbedaan asam urat pre test dan post test diberikan rebusan daun salam pada lansia di Posyandu Lansia Desa Ngembat Padas Sragen dengan nilai mean sebelum diberikan rebusan daun salam 7,264 setelah diberikan menjadi 4,750, nilai minimum sebelum diberikan rebusan daun salam 6,1 setelah diberikan menjadi 3, dan nilai maksimum sebelum diberikan rebusan daun salam 12,4 menjadi 7,1. Ada perbedaan signifikan pada asam urat yang di derita lansia penderita asam urat di Posyandu Lansia Desa Ngembat Padas Sragen post test pemberian rebusan daun salam.
\end{abstract}

Kata kunci : Daun salam, Asam urat, Lansia

\begin{abstract}
Bay leaf (Eugenia polyantha wight) commonly used by Indonesian people as kitchen spices and it also used as medicine. Bay leaf is used for the treatment of hight cholesterol, diabetes mellitus, hypertension, gastritis, diarrhea and its chemical content can used for uric acid medication. Aims this research to determine the effect of bay leaf decoction to decreasing uric acid levels. The research design used quasi experimental design and one group pre test-post test design. The sample was elderly at Posyandu Ngembat Padas Sragen with 36 people. The sampling technique used purposive sampling. Whereas, data analysis covered normality test used Shapiro-Wilk and statistical tests used parametric paired $t$-test. Based on $t$-test with paired test shows that $p$-value $=0,001<a(0.05)$. The Value of $t$ is tcount $=9.790>$ ttable $=5.99$ which means $H 0$ is rejected. It shows the difference in uric acid pretest and post-test by giving bay leaf decoction to the elderly at Posyandu Ngembat padas Sragen. The mean value in giving bay leaf of pre is 7.264 and post is 4.750. Besides, the minimum value in giving bay leaf shows that 6.1 to 3. Moreover, the maximum value in giving bay leaf shows that 12.4 to 7.1. There is a significant difference on elderly with uric acid in Posyandu Ngembat Padas Sragen after post test giving bay leaf decoction.
\end{abstract}

Keywords: Bay Leaf, Uric Acid, Elderly 


\section{PENDAHULUAN}

Dewasa ini kelebihan asam urat dalam darah (hiperurisemia) menjadi masalah serius dan merupakan penyakit degeneratif yang mengganggu kesehatan yang dapat mengakibatkan cacat secara fisik (Artini et al., 2012). Kadar asam urat berlebih biasanya menyebabkan timbulnya penyakit yang dikenal dengan nama arthritis gout (Weaver, 2008). Arthritis gout paling sering dialami pada lanjut usia (Diantri dan Chandra, 2013).

$$
\text { Pada lanjut usia terjadi }
$$

kemunduran sel-sel karena proses penuaan yang berakibat pada kelemahan organ, kemunduran fisik, timbulnya berbagai macam penyakit seperti peningkatan kadar asam urat (Andry et al., 2009). Asam urat dihasilkan oleh setiap makhluk hidup akibat proses metabolisme utama yaitu suatu proses kimia dalam inti sel yang berfungsi menunjang kelangsungan hidup. Bila terjadi penyimpangan dalam proses ini, maka asam urat akan menumpuk (Ahmad, 2011).

$\begin{array}{cc}\text { Menurut World } & \text { Health } \\ \text { Organization (WHO) tahun 2013, }\end{array}$
prevalensi penyakit asam urat mengalami kenaikan jumlah penderita hingga dua kali lipat antara tahun 1990-2010. Pada orang dewasa di Amerika Serikat penyakit asam urat mengalami peningkatan dan mempengaruhi 8,3 juta (4\%) orang Amerika.

Prevalensi penyakit asam urat di Indonesia terjadi pada usia di atas 34 tahun sebesar 68\%, penderita asam urat pada tahun 2007 diperkirakan mencapai 230 juta dan angka tersebut diperkirakan akan meningkat tajam pada tahun 2020 (Ahmad, 2011). Berdasarkan hasil Kemenkes (2013) menunjukkan bahwa penyakit sendi di Indonesia yang diagnosis tenaga kesehatan sebesar $11,9 \%$ dan prevalensi penyakit sendi di
Jawa Tengah tahun 2013 berdasarkan diagnosis tenaga kesehatan sebesar $11,2 \%$ ataupun berdasarkan diagnosis dan gejala sebesar $25,5 \%$.

Istilah gout merupakan penyakit yang menggambarkan hiperurisemia (Sibella, 2010). Hiperurisemia dapat menyebabkan nyeri, inflamasi vaskuler, proliferasi otot polos, peningkatan produksi renin, dan lesi vaskuler pada ginjal (Miftafu dan Dwi, 2016). Obatobatan penurun kadar asam urat terdiri dari golongan urikosurik dan golongan penghambat xanthine oksidase. Selain menggunakan obat konvensional seperti allopurinol, probenesid dan lainlain, hiperurisemia juga dapat diatasi dengan terapi komplementer (Putra, 2009).

Terapi komplementer merupakan terapi alamiah diantaranya adalah dengan terapi herbal. Pengobatan dengan menggunakan terapi komplementer mempunyai manfaat selain dapat meningkatkan kesehatan secara menyeluruh juga lebih murah, manfaat pengobatan dengan menggunakan terapi komplementer dirasakan oleh pasien dengan penyakit kronik yang mengeluarkan dana. Pengalaman klien yang harus membeli obat dengan harga yang mahal sehingga pengeluaran dana untuk membeli obat dapat berkurang setelah menggunakan pengobatan pengobatan komplementer. Daun salam (Syzygium Polyanthum Wight) memiliki manfaat untuk peluruh kencing (diuretik) dan anti nyeri (analgesik). Kandungan sebagai diuretik, daun salam dapat memperbanyak produksi urine sehingga dapat menurunkan kadar asam urat darah (Bangun, 2013).

Daun salam (Eugenia polyantha Wight) yang biasa dimanfaatkan oleh masyarakat Indonesia sebagai 
pelengkap bumbu dapur juga mempunyai khasiat sebagai obat. Dalam pengobatan, daun salam digunakan untuk pengobatan kolesterol tinggi, kencing manis (diabetes mellitus), tekanan darah tinggi (hipertensi), sakit maag (gastritis), diare dan kandungan kimianya mempunyai aktivitas sebagai obat asam urat (Wijayakusuma, 2010).

Menurut penelitian Ardhiyanti (2013), khasiat yang terkandung dalam daun salam mempunyai senyawasenyawa seperti minyak atsiri, tanin, dan flavonoid. Minyak atsiri dengan kandungan minyak sitrat dan eugenol yang bersifat anti bakteri dan beraroma gurih. Tanin memiliki kemampuan mereduksi dan berperan penting dalam menyerap dan menetralkan radikal bebas dan dekomposisi peroksida. Flavonoid dapat menghambat enzim xantinoksidase, yang berfungsi menghambat pembentukan asam urat. Berdasarkan hasil studi pendahuluan yang dilakukan di Posyandu Lansia Desa Ngembat Padas Sragen pada tanggal 6 bulan Januari 2019, didapatkan 40 orang lansia. Hasil wawancara kepada 15 orang lansia, para lansia banyak mengeluhkan sakit pada daerah sendi, seperti sendi pada daerah tangan, sendi pada daerah tumit dan juga pada daerah kaki. Hasil pemeriksaan terhadap 10 lansia masing-masing 5 laki-laki dan 5 perempuan, diperoleh hasil sebagai berikut: 5 lansia memiliki kadar asam urat $>8 \mathrm{mg} / \mathrm{dl}$, dan 5 lansia perempuan memiliki kadar asam urat $>7 \mathrm{mg} / \mathrm{dl}$. Para lansia juga mengatakan akibat rasa sakit yang ditimbulkan, aktivitas mereka menjadi terganggu dan mereka merasa tidak nyaman disebabkan kondisi yang sakit yang dideritanya.

Hasil wawancara kepada 10 orang lansia di Posyandu Lansia Desa
Ngembat Padas Gemolong Sragen belum ada yang mengetahui manfaat dari daun salam untuk menurunkan kadar asam urat. Berdasarkan latar belakang masalah di atas maka peneliti mengadakan penelitian dengan judul: "Pengaruh Rebusan Daun Salam Terhadap Penurunan Kadar Asam Urat Pada Lansia".

\section{METODE PENELITIAN}

Metode penelitian yang digunakan oleh peneliti adalah metode quasi eksperimen one group pre testpost test design. Dalam rancangan ini tidak ada kelompok pembanding (control) tetapi sudah dilakukan observasi pertama (pretest) yang memungkinkan menguji perubahanperubahan yang terjadi setelah adanya eksperimen (program) (Nursalam, 2017).

Berikut model tes awal-tes akhir kelompok tunggal (The one group pretest-posttest design). Paradigma desain penelitian ini terdapat pretest sebelum diberi perlakuan sehingga hasil perlakuan dapat diketahui lebih akurat, karena dapat membandingkan dengan keadaan sebelum diberi perlakuan (Syamsuddin dan Damayanti, 2011).

\section{HASIL PENELITIAN}

Berdasarkan tabel 4.1 karakteristik responden berdasarkan jenis kelamin menunjukkan mayoritas responden berjenis kelamin perempuan sebanyak 28 responden $(77,8 \%)$, sedangkan sisanya responden yang berjenis

$\begin{array}{llll}\text { kelamin laki-laki sejumlah } 8 & \end{array}$ responden (22,2\%). Karakterisktik responden berdasarkan usia menunjukkan mayoritas responden berusia seluruhnya diatas ( $>40$ tahun) sebanyak 36 responden $(100 \%)$. 


\begin{tabular}{lrrl}
\hline \multicolumn{2}{c}{ Karakteristik } & responden & responden berdasarkan pola makan \\
berdasarkan Riwayat asam urat & menunjukkan mayoritas responden \\
menunjukkan mayoritas responden & memiliki pola makan tidak baik sebanyak \\
memiliki Riwayat asam urat tinggi & 34 responden $(94,4 \%)$. Dan lainnya pola \\
seluruhnya tinggi asam urat sebanyak 36 & makan baik sebanyak 2 responden $(5,6)$. \\
responden
\end{tabular}

Tabel 4.1

Karakteristik Demografi Responden Penelitian di Posyandu Lansia Desa

Ngembat Padas Mei 2019 ( $n=36)$

\begin{tabular}{lcc}
\hline $\begin{array}{l}\text { Karakteristik } \\
\text { responden }\end{array}$ & \multicolumn{2}{c}{ Distribusi frekuensi } \\
& Frekuensi (orang) & Presentase (\%) \\
\hline Jenis Kelamin & 8 & 22,2 \\
\hline Laki-laki & 28 & 77,8 \\
Perempuan & & 100 \\
\hline Usia & 36 & 5,6 \\
\hline 45-59 tahun & & 94,4 \\
\hline Pola Makan & 2 & \\
Baik & 34 & \\
\hline
\end{tabular}




\section{Hasil Uji Univariat}

Uji univariat pada umumnya untuk menghasilkan distribusi dan persentase dari tiap variabel, yaitu dataasam urat sebelum dan sesudah diberikan rebusan daun salam.

Tabel 4.2

Distribusi Responden Penderita Asam Urat Berdasarkan Sebelum dan Sesudah diberikan Rebusan Daun Salam

\begin{tabular}{lcc} 
& \multicolumn{2}{c}{ Asam Urat } \\
& Sebelum & Sesudah \\
\hline Mean & 7,264 & 4,750 \\
Minimum & 6,1 & 3 \\
Maksimum & 12,4 & 7,1 \\
\hline
\end{tabular}

Sumber : Data primer (2019).

Dari tabel 4.2 menunjukkan asam urat subyek penelitian berdasarkan sebelum diberikan rebusan adalah 7,264 dengan asam urat minimum 6,1 dan asam urat maksimum 12,4. Sedangkan asam urat sesudah diberikan rebusan daun salam rata-rata 4,750 dengan asam urat minimum 3 dan asam maksimum 7,1.

\section{Hasil Uji Bivariat}

Analisis bivariat digunakan untuk mengukur tingkat asosiasi atau untuk mengetahui ada tidaknya pengaruh rebusan daun salam terhadap penurunan kadar asam urat. Hasil uji bivariat dengan paired test diperoleh hasil sebagai berikut:

Tabel 4.4

Hasil Uji t-test Perbedaan Asam Urat Sebelum dan Sesudah Pemberian Rebusan Daun Salam

\begin{tabular}{lccc}
\hline & Rerata & Selisih & Nilai p \\
\hline Sebelum & $7,26(1,3)$ & $2,51(1,5)$ & $<0,001$ \\
Sesudah & $4,75(1,2)$ & & \\
\hline
\end{tabular}

Sumber : Data Primer (2019)
Berdasarkan hasil tabel $4.4 \mathrm{di}$ atas hasil uji t-test, diperoleh nilai significancy 0,001 $(p<0,05)$ dengan selisih -2,51 (IK 95\%-3,03 sampai $1,99)$. Karena nilai $p<0,05$ dan IK tidak melewati nol, secara statistik terdapat perbedaan rerata pemberian rebusan daun salam yang bermakna sebelum dan sesudah selama 7 hari dan hasil rerata sebelum pemberian rebusan daun salam 7,26 dan sesudah pemberian rebusan daun salam 4,75.

\section{PEMBAHASAN}

Hasil penelitian berdasarkan $t$ test dengan paired test menunjukan hasil sebagai berikut: ada pengaruh asam urat sebelum dan sesudah pemberian rebusan daun salam yang ditunjukkan dengan nilai paired test sebelum pemberian rebusan daun salam nilai rerata 7,26 dan sesudah pemberian rebusan daun salam nilai rerata 4,75 dengan nilai $p$-value $0,001<\alpha .(0,05)$. Hal tersebut berarti lansia yang menderitaasamuratyang di rebusan daun salam akan dapat mengurangi asam urat sehingga akan membuat kadar asam urat juga menurun. Hasil penelitian ini sejalan dengan penelitian terdahulu yang telah dilakukan oleh Ardhiyanti (2013), yang berjudul pengaruh pemberian air rebusan daun salam (syzgium olyanthum weight) terhadap penurunan kadar asam urat dengan hiperurisemia di Desa Leyengan Kecamatan Ungaran Timur Kabupaten Semarang tahun 2013. Hasil dari penelitian tersebut adalah ada pengaruh pemberian air rebusan daun salam terhadap penurunan kadar asam urat dengan hiperurisemia ( $p$ value sebesar $0,021<\alpha(0,05)$.

Hal tersebut dapat terjadi karena dipengaruhi oleh beberapa faktor baik dari responden yang kooperatif maupun 
dari manfaat daun salam jika dilakukan sesuai prosedur dan dengan frekuensi yang teratur serta faktor diet yang mereka jalani selama proses penelitian berlangsung (Sumono dan Agustin 2008). Sesuai yang di ungkapkan oleh Herliana (2013), khasiat yang terkandung dalam daun salam mempunyai beberapa senyawasenyawa seperti minyak atsiri, tannin, dan flavonoid yang banyak terdapat dalam daunnya. Kandungan dalam daun salam tersebut yang dapat menurunkan kadar asam urat dengan jalan menghambat kerja enzim xantin oksidase sehingga dapat menghambat pembentukan asam urat.

Senyawa flavonoid dapat menghambat enzim xantin oksidase disebabkan oleh adanya gugus hidroksil pada atom C-5 atau C-7 serta adanya ikatan rangkap antara $\mathrm{C}-2$ atau $\mathrm{C}-3$ yang memungkinkan terjadi reaksi adisi (oksidase oleh xantin oksidase) sehingga cincin $\mathrm{B}$ menjadi co-plannar terdapat cincin A dan C (Muhtadi, et al., 2012). Kemampuan flavonoid dalam menghambat aktivitas xantin oksidase yaitu melalui mekanisme inhibisi kompetitif dan interaksi dengan enzim pada gugus samping (Enda, 2009).

\section{DAFTAR PUSTAKA}

Agoes, A. (2010). Tanaman Obat Indonesia. Buku 2. Jakarta: Salemba Medika

Ahmad, Nablory. (2011). Cara Mencegah dan Mengobati Asam Urat dan Hipertensi. Jakarta: Rineka Cipta

Andriani A, Chaidir R. (2016). Pengaruh Pemberian Air Rebusan Daun Salam (Syizygium Polyanthum)Terhadap Penurunan Kadar Asam Urat.
JurnalIPTEKS Terapan, Vol. 10 No. 2.

Andry, Saryono, Arif Setyo Upoyo. (2009). Analisis Faktor-Faktor yang Mempengaruhi Kadar Asam Urat pada Pekerja Kantor di Desa Karang Turi,

Kecamatan Bumiayu, Kabupaten Brebes. Jurnal Keperawatan Soedirman (The Soedirman Journal of Nursing), Vol. 4 No. 1.

Ardhiyanti, Ni Wayan Rhacik. (2013).

"Pengaruh Pemberian Air

Rebusan Daun Salam

(Syzgium Polyantum W)

Terhadap Penurunan Kadar Asam Urat Dengan

Hiperurisemia Di Desa

Leyangan Kecamatan Ungaran

Timur Kabupaten Semarang".

Arikunto, Suharsimi. (2010). Prosedur

Penelitian Suatu Pendekatan

Praktik. Jakarta: Rineka Cipta.

Artini, N. P. R., Sri, W, Wahyu, D. S.

(2012). Ekstrak Daun Sirsak

(Annona muricata Linn) Sebagai

Antioksidan Pada Penurunan

Kadar Asam Urat Tikus Wistar. Jurnal Kimia, Vol. 6 No. 2.

Aru. W. Sudoyo. (2014). Ilmu Penyakit Dalam. Jilid 1. Jakarta : Interna Publishing.

Bangun. (2013). Sehat dan Bugar Pada Lanjut Usia dengan Jus Buah dan Sayuran. Jakarta : Agromedia Pustaka.

Candrawati. (2010). Efek pemberian Ekstrak Daun Seledri (Apium 


graveolens Linn) Terhadap
Penurunan Kadar Asam Urat
Tikus Putih Jantan (Rattus
norvegicus). Fakultas Farmasi
Universitas Katolik Widya
Mandala. Surabaya.

Dalimartha, S.(2008). Resep Tumbuhan Obat Untuk Asam Urat, Jakarta : Penebar Swadaya

Dianati, N. A. (2015). Gout dan Hiperurisemia. J Majority, Vol. 4 No. 3.

Diantri dan Chandra. (2013). Pengaruh Asupan Purin dan Cairan terhadap Kadar Asam Urat Wanita Usia 50-60 Tahun di Kecamatan Gajah Mungkur, Semarang. Journal of Nutrition College, Vol. 2 No.2

Departemen Kesehatan Republik Indonesia. (2013). Laporan Hasil Riset Kesehatan Dasar(Riskesdas). Jakarta Depkes RI.

Departemen Pendidikan Nasional. (2014). Kamus Besar Bahasa Indonesia Pusat Bahasa. Jakarta : Gramedia.

Desi Alvionita, D. Sevilia., Mumpuni, D. (2016). Pengaruh Konsumsi Jus Nanas Terhadap Penurunan Kadar Asam Urat pada Lansia di UPT Panti Werdha Mojopahit Mojokerto., journal.stikespemkabjombang.a c.id., Diakses pada 10 Februai 2019
Dewanti Sisilia, M. dan Teguh Wahyudi. (2011). Uji Aktivitas Antimikroba Infusum Daun Salam (FoliaSyzygiumpoly polyanthum Wight) Terhadap Pertumbuhan Bakteri Escherichia Coli Secara InVitro. Jurnal Medika Planta, Vol. 1 No.4.

Doherty, Michael. (2009).New insight into the apidemiology of gout, Available from rheumatology.oxforjournals.Org. , Diakses tanggal 22 November 2018.

Dorland, W. A. N. (2010). Kamus kedokteran dorland, edisi 31. EGC.

Effendi, F dan Makhfudi. (2009) . Keperawatan Kesehatan Komunitas : Teori dan Praktek Dalam Keperawatan. Jakarta : Salemba Medika.

Ekasari, Wiwied. (2018). Tanaman dan Kesehatan. Sidoarjo : Indomedia Pustaka.

Ellin, Puji Aprillia. (2018). Pengaruh Pemberian Rebusan Daun Salam Terhadap Penurunan Kadar Asam Urat Pada Lansia, respo.stikesicme-jbg.ac.id., Diakses pada 12 Maret 2019

Enda. W. G (2009). Uji Efek Antidiare Ekstrak Etanol Kulit Batang Salam (Sygygium polyanthum (Wight) Walp). Terhadap Mencit Jantan. Medan: Fakultas Farmasi Universitas Sumatera Utara. 
Fauziah, A. (2013). Hubungan Pola Makan Dengan Frekuensi Kekambuhan Nyeri Pada Pasien Gout. Journal Lanjut Usia Di Puskesmas Wawonasa Manado. E-Journal Keperawatan (e-Kp) Volume 3 Nomor 3 Agustus 2015. Diakses pada 5 Juni 2019.

Guyton, A. C., dan Hall, J. E. (2014). Buku Ajar Fisiologi Kedokteran. Edisi 12. Jakarta : EGC.

Har, L. W. dan Ismail, I. S. (2012). Antioxidant activity, total phenolics and total flavanoids of Syzygium polyanthum (Wight) Walp leaves. International Journal of Medical Aromatic Plants, Volume 2 Nomor 2.

Helmi, Z. N. (2012). Buku Ajar Gangguan Muskuloskeletal, Jakarta: Salemba Medika.

Herliana, Ersi. 2013. Penyakit Asam Urat. Jakarta: Fmedia.

Hidayat, A. A., Alimul. (2017).

Metodologi Penelitian Keperawatan dan Kesehatan. Jakarta: Salemba Medika.

Joshi, U. H., T. H. Ganatra, P. N. Bhalodiya, T. R. Desai, damn P. R. Tirgar. (2012). Comparative Review on Harmless Herbs with Allophatic

Remedies As

Anti-

Hypertensive. Research Journal of Pharmaceutical, Biological and Chemcical Science.
Junaidi, I. (2013) Rematik dan Asam Urat. Jakarta: Bhuana Ilmu Populer.

Kemenkes RI. (2013). Gambaran Kesehatan Lanjut Usia di Indonesia. Buletin Jendela: Jakarta.

Kementerian Kesehatan RI. (2013). Pengobatan Komplementer Tradisional-Alternatif, http://buk.depkes.go.id., Diakses pada 8 Januari 2019

Kementrian Kesehatan RI. (2014). Pusat Data dan Informasi. Jakarta Selatan.

Kertia, N. (2009). Asam Urat. Yogyakarta : Kartika Media..

Kumalasari, Tyas S. (2009). Hubungan indeks masa tubuh dengan kadar asam urat darah pada penduduk desa Banjaranyar Kecamatan Sokaraja kabupaten Banyumas. Universitas Jenderal Soedirman.

Kurniawan,P.(2011) .Pencegahan Pendidikan Kesehatan Arthritis Gout Terhadap Pencegahan Arthritis Gout Pada Lansia Di Posyandu Kedungtangkil Karangsari Pengasih Kulon Progo. Yogyakarta : Stikes Aisyiyah Yogyakarta.

Mahmud D. (2008). Buku Pintar Sehat Seumur Hidup. Yayasan Media Kesehatan Alternatif Sarana Bantuan Kesehatan, Jakarta.

Mandell, B. F. (2008). Clinical Manifestations of Hyperuricemia and Gout, 
Cleveland, Clinic Journal of Medicine, Vol. 75 No. 5.

Maryam, R. Siti., Ekasari, Mia Fatma., Rosidawati., Ahmad Jubaedi., \& Irwan Batubara. (2011) . Mengenal Usia Lanjut dan Perawatannya. Jakarta: Salemba Medika.

Miftafu, D. dan Dwi K. Rukmi. (2016) . Peran Air Rebusan Daun Salam (Syzgium Polyanthum) Dalam Menurunkan Kadar Asam Urat. Media Ilmu Kesehatan.Vol. 5 No. 2.

Muhajir, N. F., S. T . Widada, dan B. Afuranto. (2012). Hubungan Antara Usia dengan Kadar Asam Urat darah di

Laboratorium Puskesmas Srimulyo, Triharjo, Sleman, Yogyakarta Tahun 2012. Ejournal Poltekkes Denpasar. Diakses pada 5 Juni 2019.

Muhtadi, Retnani. I, Wahyuningtyas. N. (2012). Penghambatan Ksantin Oksidase Oleh Kombinasi Ekstrak Tempuyung (Soncus Arvensis) Dan Salam (Syzygium Polyanthum) Pada Mencit

Hiperurisemia

Biomedika. Vol. 4. No 1.

Ningsih, Sri Wahyu. (2014). Gambaran Asupan Purin dan Penyakit Artritis Gout Serta Kualitas Hidup Lanjut Usia di Kecamatan Tamalanrea, www.adln.Lib.Unhas.ac.id.go., Diakses pada 23 Oktober 2018.
Ningtyas. I. F, Ramadhian. M. R. (2016). Efektivitas Daun Salam Untuk Menurunkan Kadar Asam Urat Pada Penderita Arthritis Gout. Majority. Vol. 5 No 3.

Notoatmodjo, Soekidjo. (2010). Metodologi Penelitian Ilmu Keperawatan. Jakarta : Salemba Medika

Nugroho, W. (2012) . Keperawatan Gerontik \& Geriatrik. Edisi 3. Jakarta : Balai Penerbit EGC.

Nursalam. (2017). Konsep dan Penerapan Metodologi Penelitian Ilmu Keperawatan. Jakarta : Salemba Medika

Pipit, Festi. (2010). Hubungan Antara Pola Makan Dengan Kadar Asam Urat Darah Pada Wanita Post Menopause di Posyandu Lansia Wilayah Kerja Puskesmas Dr. Soetomo Surabaya. Diakses pada 5 Juni 2019.

Price, Sylvia. A . (2008) . Patofisiologi : Konsep Klinis Proses-proses Penyakit. Ed. 6 ; Cet. 1 ; Jil. II. Jakarta : EGC

Putra T. R. (2009). Hiperurisemia. Dalam: Sudoyo dkk. Buku Ajar Ilmu Penyakit Dalam Jilid III Edisi V. Jakarta: Interna Publishing

Rini, Setyoningsih. (2009). FaktorFaktor yang Berhubungan dengan Kejadian Hiperurisemia pada Pasien Rawat Jalan RSUP Dr. Kariadi Semarang. 
Artikel Penelitian: Semarang.

Roddy, E dan Doherty, M. (2010). Epidemiology of Gout, Arthritis Reseacrh and Therapy. Diakses pada 12 Februari 2019. http://arthritisreseacrh.com/ cont ent/12/6/223.

Sibella, Rifdah. (2010). Libas Asam Urat Dengan Terapi Herbal, Buah, Sayuran. Klaten : Galmas Publisir.

Soeroso. J, Algristian. H. (2011).

Asam Urat,Jakarta: Penebar Plus.

Stapleton A. Phoebe, Adam G. Goodwill, Jefferson C. Frisbee. (2010). Hypercholestrolemiaans Microvascular Dysfunction International strategies, Journal of Inflammation 7 : 54 , http://www.journalinflammation.com/content., Diakses pada 15 Februari 2019.

Stoppard, Miriam. (2010). Pendidik

Kesehatan Keluarga. Jakarta Erlangga.

Sugiyono. (2010). Metode Penelitian Pendidikan Pendekatan Kuantitatif, kualitatif dan $R \& D$. Bandung : Alfabeta.

Suiraoka, I. P., dan Supariasa, I. D. (2012). Media Pendidikan Kesehatan. Yogyakarta: Graha Ilmu.
Sujarweni, V. Wiratna. (2014). Metode Penelitian: Lengkap, Praktis, dan Mudah Dipahami. Yogyakarta : Pustaka Baru Press.

Sumono, A. dan Agustin, W. S. D. (2008). The User of Bay Leaf (Eugenia polyanthaWight) in dentistry. Dentistry Journal, Vol. 41 No. 3.

Sustrani. (2009). Asam Urat. Jakarta: PT. Gramedia Utama.

Syamsuddin dan Damayanti. (2011). Metode Penelitian Pendidikan Bahasa. Bandung : Remaja Rosdakarya.

Tehupeiory, E. S. (2008). Artritis Gout dalam Buku Ajar Ilmu Penyakit Dalam. Jakarta : FKUI.

Utami, P. dan Puspaningtyas. D. E. (2013). The miracle of herbs. Jakarta: Agro Media Pustaka.

Wahyuningsih, R. (2013). Penatalaksanaan Diet Pada Pasien. Yogyakarta: Graha Ilmu.

Weaver, A., L.(2008) . Epidemiology of Gout, Cleveland Clinic Journal of Medicine, Vol.75 No. 5.

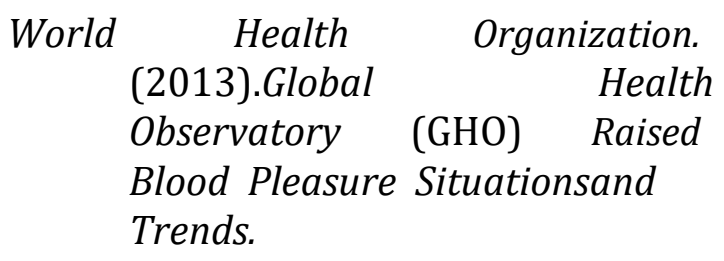

Widyatuti, W. (2012) . Terapi Komplementer dalam Keperawatan. Diakses dari : 
Jurnal Perawat Indonesia, Volume 4 No 2, Hal, 413-423 Agustus 2020

http://www.jki.ui.ac.id/index.ph p /jki. Pada tanggal 7 Desember 2018.

Wijayakusuma, H. (2010). Atasi Asam Urat dan Rematik. Jakarta : PuspaSwara. 